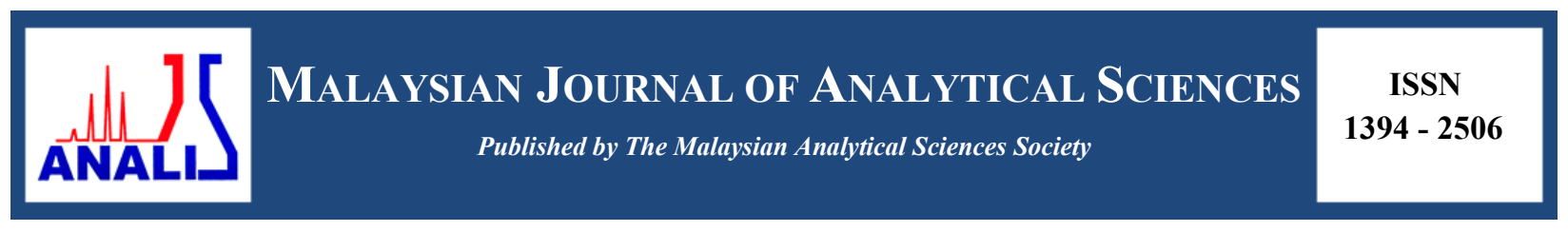

\title{
CHARACTERIZATION OF SODIUM SILICATE DERIVED FROM SUGARCANE BAGASSE ASH
}

\author{
(Pencirian Natrium Silikat yang Dihasilkan daripada Abu Hampas Tebu) \\ Norsuraya Sahiron, Norhasyimi Rahmat, Fazlena Hamzah* \\ Faculty of Chemical Engineering \\ Universiti Teknologi MARA, 40450 Shah Alam, Selangor, Malaysia \\ *Corresponding author: fazlena@salam.uitm.edu.my
}

Received: 21 October 2015; Accepted: 14 June 2016

\begin{abstract}
This study explores the potential of sugarcane bagasse ash (SCBA) as a precursor in the extraction of sodium silicate. SCBA was obtained from sugarcane bagasse, residual waste from sugar industries. In the present study, sugarcane bagasse (SCB) was burnt with different temperatures $600{ }^{\circ} \mathrm{C}, 800{ }^{\circ} \mathrm{C}$ and $1000^{\circ} \mathrm{C}$ for 2 hours and 4 hours and then the ash washed using hydrochloric acid $(\mathrm{HCl})$ to remove metallic ions and impurities. The ash was characterized using X-ray Fluorescence (XRF). The result indicated that SCBA at $1000{ }^{\circ} \mathrm{C}$ for 4 hours using acid washing method gave the highest composition of silica which is $88.13 \%$. Then, the ash with the highest silica composition was extracted using $3 \mathrm{M}$ of sodium hydroxide $(\mathrm{NaOH})$ solution. During the process $\mathrm{NaOH}$ will bind with silicate to form sodium silicate $\left(\mathrm{Na}_{2} \mathrm{SiO}_{2}\right)$ and water $\left(\mathrm{H}_{2} \mathrm{O}\right)$. The formation of sodium silicate was characterized and compare with commercial sodium silicate using Fourier Transform Infrared Spectroscopy.
\end{abstract}

Keywords: sodium silicate, sugarcane bagasse ash, waste renewable

\begin{abstract}
Abstrak
Kajian ini meneroka potensi abu hampas tebu (SCBA) sebagai pelopor dalam pengekstrakan natrium silikat. Abu hampas tebu ini telah diperolehi daripada industri gula. Dalam kajian ini, hampas tebu (SCB) dibakar dengan suhu yang berbeza iaitu pada suhu $600{ }^{\circ} \mathrm{C}, 800^{\circ} \mathrm{C}$ dan $1000^{\circ} \mathrm{C}$ selama 2 jam dan 4 jam dan kemudian abu dicampur dengan asid hidroklorik ( $\left.\mathrm{HCl}\right)$ dan ditapis untuk mengeluarkan ion logam dan kekotoran. Abu di analisis menggunakan pendarfluor Sinar-X (XRF). Hasilnya menunjukkan bahawa abu hampas tebu (SCBA) pada $1000{ }^{\circ} \mathrm{C}$ selama 4 jam dengan menggunakan kaedah basuhan asid memberikan komposisi silika tertinggi iaitu $88.13 \%$. Kemudian, abu dengan komposisi silika yang paling tinggi akan diekstrak menggunakan $3 \mathrm{M}$ natrium hidroksida $(\mathrm{NaOH})$. Semasa proses, $\mathrm{NaOH}$ akan bergabung dengan silikat untuk membentuk natrium silikat $\left(\mathrm{Na}_{2} \mathrm{SiO}_{2}\right)$ dan air $\left(\mathrm{H}_{2} \mathrm{O}\right)$. Pembentukan natrium silika dianalisis dan bandingkan dengan silika natrium yang digunakan dipasaran menggunakan Spektroskopi Inframerah Transformasi Fourier.
\end{abstract}

Kata kunci: natrium silikat, hampas tebu, sisa diperbaharui

\section{Introduction}

Sugarcane or Saccharum officinarum L. is a perennial grass that thrives in hot and humid locations. It is originated in Papua, New Guinea and spread throughout Southeast Asia, India, the Mediterranean, Caribbean, Hawaii and the southern United States. According to Jorina [1], the structures of sugarcane comprised of stalks, leaves and a root system. The stalk contains the juice which used to make sugar and is broken up in segments called joints. The length and diameter of the joints and stalk vary by sugarcane species. Each joint has a node and an inter node and the leaves are attached to the node. The root system at the base of the plant anchors the grass to the soil and adsorb 
in water and nutrients from the ground. When the top part of the sugarcane is cut, the roots remain intact, the plant will regrow from where it was cut. It can take about six to 24 months for the plant to grow to maturity [1]. Sugarcane is harvested when it reaches maturity and during the dry season of the particular sugar cane plantation. The sugarcane juice extract from the stalk is highly valued and is the source of 70 percent of the world's sugar and has the highest number of calories per unit area of any plant [1]. The sugars derived from sugarcane are commonly used in syrups, juices, and molasses. After juice was extract from stalks, the waste left is called sugarcane bagasse (SCB). The main constituents of SCB include cellulose, hemicellulose, ash and wax [2].

In Malaysia, large region of northern area is devoted to sugarcane plantation, which produces more than 700000 tonnes of sugarcane. This waste from sugarcane was abundance in Malaysia and usually used as a primary fuel source and additive in construction industries [3]. Normally for every metric ton of sugarcane production, $270 \mathrm{~kg}$ bagasse is generated. Approximately $50 \%$ amount of this waste generally will be reused for energy and bioethanol application, while the remaining $50 \%$ will be stockpiled or burnt that could pose environmental problem [4]. From biomass viewpoint, sugarcane plantation produces not only granulated sugar, but also bagasse, cane tops and dry leaves that potentially could be converted into useful energy and chemical feedstock. SCB itself contributes to the main biomass wastes, which represents $30-40 \%$ wastes from sugar production. Wide array of initiatives has been taken by researchers and scientist to utilize the SCB waste, one of which is sugarcane bagasse ash as the supplementary material in cement construction [5]. Several studies have investigated bagasse ash potential applications such as producing silica gel as adsorbent, raw material for ceramic, cements and concrete additives, catalyst, cosmetics, paint and coating, etc. based on its characteristics. SCB is a potential feedstock that can be convert to sugarcane bagasse ash (SCBA) by pyrolysis process which also known to be a renewable resource for silica content.

In local plantation it was a valuable by products that often uses as a primary fuel source to supply all the energy needs to power the plants. Burning bagasse as an energy source yields its ash, considered as a waste causing disposal problems. Therefore, this study will show that burning sugarcane bagasse will produce a valuable product through extraction process which is sodium silicate. Sodium silicate has been diligently produced from utilizing waste from sugar industry, SCBA. Currently in market, sodium silicate was synthesized by petroleum derivatives which are identified to be toxic and environmentally unfriendly. Moreover, the processing is very costly, in which total cost of raw material passes through different cycles of process is estimated to be expensive. Unlike the production of sodium silicate from SCBA, a green and economical approach has been developed to convert the SCB to ash through burning in laboratory furnace. It is then extracted and treated by simplified chemical methods to produce high purity of sodium silicate, and the cost involved is very minimal. The SCBA is preferable as a source for silicate production since it is renewable, available in Malaysia, cheap, natural, less toxic and high silica content. So, this seems to open a wide possibility of developing the silica precursor from SCBA. In order to achieve the goal of the study, the waste material which is Sugarcane bagasse was utilize as a source of silica and determine the potential of SCB as a source of silicate. However, this ash have a potential to be reused in other application due to it silica composition. According to Worthanakul et al., on the study of Characterization for Post-treatment Effect of Bagasse Ash for Silica Extraction, the silica content in SCBA might range from $60 \%$ to $89 \%$. The silica contents of bagasse and its ash vary depending on the type of soil, environment and harvesting period and process [6].

This study helps to determine the effect of varying parameters of temperature, curing time and acid washing method on the composition of silica present in the SCBA. Sodium silicate produced from this project can be utilized and applied in different applications i.e. detergent auxiliaries, adhesive use, concrete and cement treatment, as agent for drilling fluids, silica source for synthesis of mesoporous materials [7].

\section{Materials}

\section{Materials and Methods}

Silicate Supernatant Extraction was carried out using SCBA in order to extract silica for the further study. This study focus on the performance of thermochemical treatment to extract maximum amount of silica and also the performance of that sodium silicate as a silica source. Sugarcane bagasse were collected from juice processes industry (small industry). The bagasse was cut to ensure complete burning. Then SCB were pyrolysis in the laboratory furnace (CARBOLITE RHF 16-8 Chamber Furnace) at different heating temperature which is $600{ }^{\circ} \mathrm{C}$, 
$800{ }^{\circ} \mathrm{C}$ and $1000{ }^{\circ} \mathrm{C}$, respectively for 2 hours and 4 hours. The collected bagasse ash will be grinded and sieved to homogenize sample.

\section{Analysis of chemical composition in sugarcane bagasses ash}

The binder was used to compress SCBA into solid form (coin shape), by using hand compression at 40 psi. After that, the sample in solid form were put in X-ray Fluorescence (XRF) sample case and arranged in the prescribed positions in the machine, then the sample case was located in analysis hole and the result of the chemical composition of each sample was displayed after 1 minute on a monitor of a computer interfaced with the machine. Then, the ash with the highest silica composition was proceed with acid washing and silica extraction method.

\section{Acid washing to remove the impurities}

The process started with 5 gram of SCBA was dispersed into $50 \mathrm{~mL}$ of $1 \mathrm{M}$ Hydrochloric solution ( $\mathrm{HCl}$ ), the suspension is then stirred for 2 hours at room temperature. The suspension obtain was filtered by Whatman No. 41 ashless filter paper and the solid residue was washed with $30 \mathrm{~mL}$ of distilled water to remove metallic ions completely. The washings are collected and dried for 24 hours at $60{ }^{\circ} \mathrm{C}$ for further process.

\section{Silica supernatant extraction}

Treatment with alkali is very effective in altering the chemical and physical structure and to remove metal impurities. The SCBA residue was dispersed in $50 \mathrm{ml}$ of $3 \mathrm{M}$ of Sodium Hydroxide solution. The mixture was boiled for 4 hours at $80^{\circ} \mathrm{C}$, vigorous stirred and reaction time was varied during this process to produce sodium silicate solution. The suspension was then filtered through an ashless Whatman No 41 in order to remove carbon residue. The filtrate solution obtain was characterized for determination of sodium silicate.

\section{Fourier transform infrared spectroscopy analysis}

Fourier transform infrared spectroscopy (FTIR Perkin Elmer, USA) was used to analyze the functional group of the sample. As the sample used was in liquid form, then the dropper was used to spread liquid sample over the plate and the sample was scan to identify specific functional group presence. Absorption bands were used to confirm the identity of a pure compound or to detect the presence of specific impurities.

\section{Sugarcane bagasses ash}

\section{Results and Discussion}

The SCBA obtained from pyrolysis process in the laboratory furnace (CARBOLITE RHF 16-8 Chamber Furnace) at different heating temperature was shown in Figure 1.

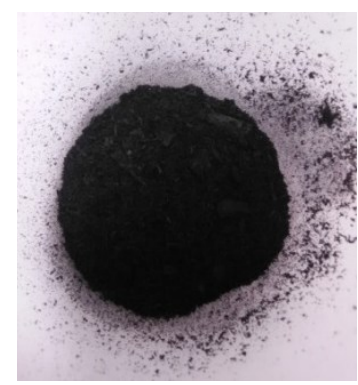

$600^{\circ} \mathrm{C}$

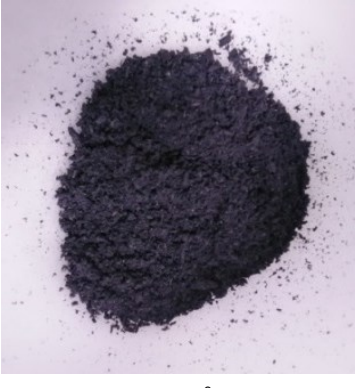

$800{ }^{\circ} \mathrm{C}$

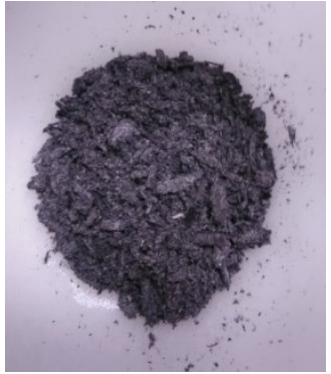

$1000^{\circ} \mathrm{C}$

Figure 1. Observation of SCBA colour at different temperature

The ashes obtained at $600{ }^{\circ} \mathrm{C}$ were dark in colour indicating the presence of unburnt carbon, while the ones heated at $800{ }^{\circ} \mathrm{C}$ and $1000{ }^{\circ} \mathrm{C}$ were slightly milky white and as temperature increases the amount of ash produced decreases 
because they will be less carbon deposits. SCBA obtain after burning in laboratory furnace and have been analyze using X-ray fluorescent (XRF) analysis, the result was tabulated in Table 1.

Table 1. Compositions of silica in SCBA at different temperature and time

\begin{tabular}{lcccc}
\hline \multirow{2}{*}{$\begin{array}{c}\text { Temperature } \\
\text { ( C) }\end{array}$} & \multicolumn{4}{c}{ Composition of Silica in SCBA (wt. \%) } \\
\cline { 2 - 5 } & \multicolumn{2}{c}{ Without Acid Washing } & \multicolumn{2}{c}{ After Acid Washing } \\
\cline { 2 - 5 } & 2 Hours & 4 Hours & 2 Hours & 4 Hours \\
\hline 600 & 37.76 & 40.25 & 74.14 & 76.83 \\
800 & 42.47 & 43.62 & 82.78 & 83.18 \\
1000 & 52.39 & 53.05 & 86.72 & 88.13 \\
\hline
\end{tabular}

\section{Effect of temperature and time on the silica composition}

The effect of times and temperature on the composition of silica present in the SCBA is shown in Table 1. Based on the overall analysis result without acid washing, 4 hours burning time were gave higher silica composition than 2 hours burning time. At temperature $600{ }^{\circ} \mathrm{C}$ without acid washing method, silica composition at 4 hour is $40.25 \%$ compare to 2 hours burning time which is only $37.76 \%$ of silica content. There are about $2.49 \%$ different of silica composition. While at temperature $800{ }^{\circ} \mathrm{C}$ the amount of silica was observed between 2 hours and 4 hours burning time are $42.47 \%$ and $43.62 \%$, respectively which gave the different about $1.15 \%$. Finally, at temperature $1000{ }^{\circ} \mathrm{C}$, the composition of silica present at 2 hours and 4 hour are $52.39 \%$ and $53.05 \%$ respectively. So, the different is only $0.66 \%$. Therefore, $1000{ }^{\circ} \mathrm{C}$ at 4 hours burning time without acid washing method give the highest silica composition which is $53.05 \%$. But, there are does not much differences in composition between the 2 and 4 hour burning times.

\section{Effect of acid washing method on the silica composition}

The silica composition of SCBA which undergoes acid washing method at $600{ }^{\circ} \mathrm{C}, 800{ }^{\circ} \mathrm{C}$ and $1000{ }^{\circ} \mathrm{C}$ reveal that 4 hours burning time produce more silica amount compared to 2 hours burning time. Even there is a little difference in composition but both 2 and 4 hours burning time give the higher amount of silica content. By referring to the Table 1 , amount of silica composition at $600{ }^{\circ} \mathrm{C}, 800{ }^{\circ} \mathrm{C}$ and $1000{ }^{\circ} \mathrm{C}$ at 2 hours are $74.14 \%, 82.78 \%$ and $86.72 \%$, respectively. While quantities of silica observed at $600{ }^{\circ} \mathrm{C}, 800{ }^{\circ} \mathrm{C}$ and $1000{ }^{\circ} \mathrm{C}$ at 4 hours are $76.83 \%, 83.18 \%$ and $88.13 \%$ respectively. The pattern of the silica composition exists in the three different temperature was slightly increase from temperature $600{ }^{\circ} \mathrm{C}$ to $1000{ }^{\circ} \mathrm{C}$. This is because at the higher burning temperature can improve the amount of silica present but the temperature must not exceed the silica melting point which is $1600^{\circ} \mathrm{C}$. Hence, from the Table 1 , temperature at $1000{ }^{\circ} \mathrm{C}$ with 4 hours burning time with undergoes acid washing method give the highest silica composition which is $88.13 \%$. Therefore, time and temperature are the most important parameter in order to achieve highest silica composition. Thus, suitable combination of time and temperature would help to improve the silica composition present.

As in the result, the composition of silica using acid washing method is higher than without using acid washing method for all samples, this is because the acid washing method helps to remove the impurities from the sugarcane bagasse ash. From the three temperature, $600^{\circ} \mathrm{C}, 800^{\circ} \mathrm{C}$ and $1000^{\circ} \mathrm{C}$, the composition of silica at $800^{\circ} \mathrm{C}$ burning for 4 hours and undergoes acid washing was give highest composition which is $88.13 \%$. The result was compared with Worthanakul et al. [6], on the study of characterization for post-treatment effect of bagasse ash for silica extraction, reveal almost the same result observed where acid washing method improved the composition of silica in the ash. But, the silica composition obtained by Worthanakul et al. was higher which is achieved at $89 \%$ [6]. Silica content of bagasse and its ash vary depending on the type of soil, environment and harvesting period and other process involve in sugarcane plantation. 


\section{Fourier transform infrared spectroscopy analysis}

The functioning group for the commercial sodium silicate and extracted sodium silicate from SCBA was illustrated in Figure 2. The comparison spectrum structure of commercial sodium silicate and extracted sodium silicate was clearly shown. Theoretically, Fourier transform infrared spectroscopy measures the absorption of infrared spectrum radiation by the sample material versus wavenumber. The infrared absorption bands will identify molecular structures and components exist in the sample. When a sample is irradiated with infrared radiation, absorbed IR radiation usually excites molecules into a higher vibration state. The wavelength of light absorbed by a particular molecule is a function of the energy difference between the at-rest and excited vibration states. The wavelengths that are absorbed by the sample are characteristic of its molecular structure. The functioning group of the single molecules was represented according to the result, absorption bands in the range of $400 \mathrm{~cm}^{-1}$ to $4400 \mathrm{~cm}^{-1}$ wavenumbers are typically due to functional groups $\mathrm{Si}, \mathrm{O}$ and $\mathrm{H}$. The patterns of the result obtain almost the same, at peak $969 \mathrm{~cm}^{-1}$, the wavenumber represent the Si-O-Si stretching. Both spectrums appear at peak $3239 \mathrm{~cm}^{-1}$ confirms the presence of hydroxyl group in the sample. Peak observed at $1646 \mathrm{~cm}^{-1}$ confirm the presence of $\mathrm{H}-\mathrm{O}-\mathrm{H}$ (water adsorption) and at peak $871 \mathrm{~cm}^{-1}$ confirm the presence of $\mathrm{SiO}_{4}$ tetrahedron. Absorption bands in this region are generally due to intramolecular phenomena and are highly specific to each material. Therefore, all peak that present in commercial sodium silicate also present in extracted sodium silicate from sugarcane bagasse ash.

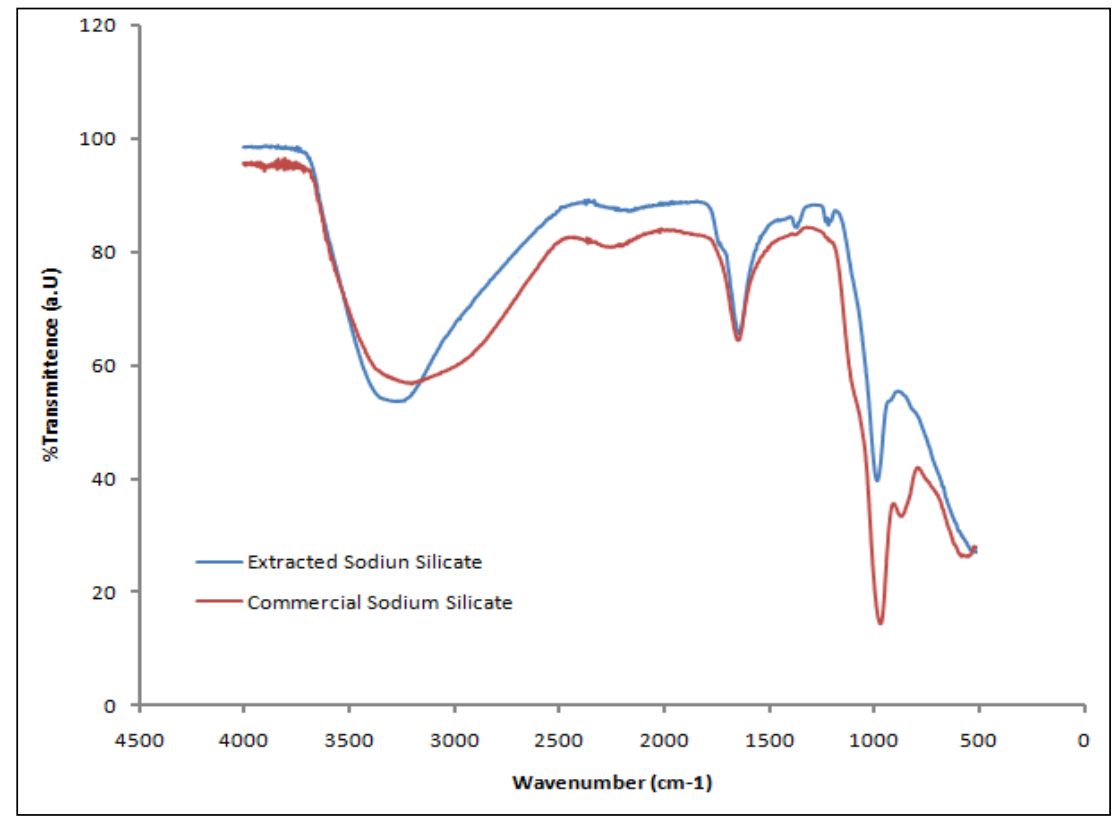

Figure 2. The FTIR spectrums of commercial sodium silicate and extracted sodium silicate from SCBA

\section{Conclusion}

Four hours burning time for all three different temperatures gave higher silica composition than 2 hours burning time. Amount of silica composition without acid washing method at temperature $600{ }^{\circ} \mathrm{C}, 800{ }^{\circ} \mathrm{C}$ and $1000{ }^{\circ} \mathrm{C}$ for 2 hour burning time are $37.76 \%, 42.47 \%$ and $52.38 \%$ respectively. While at 4 hours, the amount of silica recorded at $40.25 \%, 43.62 \%$ and $53.05 \%$, respectively. On the other hand, the silica composition for the sugarcane ash that undergoes acid washing method was give the same result, while 4 hours burning time give higher silica amount than 2 hours. An amount of $88.13 \%$ is highest composition of silica obtain at temperature $1000{ }^{\circ} \mathrm{C}$ for 4 hour with acid washing method. The patterns of the result obtain from Fourier transform-infrared spectroscopy analysis was almost the same, the peak present at $969 \mathrm{~cm}^{-1}, 3239 \mathrm{~cm}^{-1}, 1646 \mathrm{~cm}^{-1}$ and $871 \mathrm{~cm}^{-1}$ wavenumbers are typically due to present of functional groups $\mathrm{Si}, \mathrm{O}$ and $\mathrm{H}$, hydroxyl group, $\mathrm{Si}-\mathrm{O}-\mathrm{Si}$ stretching, $\mathrm{H}-\mathrm{OH}$ (water adsorption) and $\mathrm{SiO} 4$ 
tetrahedron, respectively. Therefore, the property and functional group exist in extracted sodium silicate from sugarcane bagasse ash (SCBA) was same as commercial sodium silicate in the market.

\section{Acknowledgement}

The present research was made possible through a Research Grant FRGS 5/3 (94/2013) and also facilities and constant encouragement from Faculty of Chemical Engineering, Universiti Teknologi MARA (UiTM) is gratefully acknowledged.

\section{References}

1. Jorina, F. (2012). What is sugarcane? Access online http://www.ehow.com/about_5426719_sugar-cane.html. Retrieved on $3^{\text {rd }}$ November 2014.

2. Rebitanim, N. Z., Ghani, W. A. W. A. K., Rebitanim, N. A. and Salleh, M. A. M. (2013). Potential applications of wastes from energy generation particularly biochar in Malaysia. Renewable and Sustainable Energy Reviews, 21: $694-702$.

3. Payá, J., Monzó, J., Borrachero, M. V., Díaz-Pinzón, L. and Ordónez, L. M. (2002). Sugar-cane bagasse ash (SCBA): Studies on its properties for reusing in concrete production. Journal of Chemical Technology and Biotechnology, 77(3): $321-325$.

4. Madurwar, M. V, Mandavgane, S. A. and Ralegaonkar, R. V. (2014). Use of sugarcane bagasse ash as brick material. Current Science, 107(6): 1044 - 1051.

5. Loh, Y. R., Sujan, D., Rahman, M. E. and Das, C. A. (2013). Sugarcane bagasse-the future composite material: A literature review. Resources, Conservation and Recycling, 75: 14 - 22.

6. Worathanakul, P., Payubnop, W. and Muangpet A. (2009). Characterization for post-treatment effect of bagasse ash for silica extraction. World Academy of Science, Engineering and Technology, 56: 360 - 362.

7. Sales, A. and Lima, S. A. (2010). Use of Brazilian sugarcane bagasse ash in concrete as sand replacement. Waste Management, 30(6): 1114 - 1122. 